\title{
EFEITOS DO CÁDMIO SOBRE O CRESCIMENTO DAS LEVEDURAS Saccharomyces cerevisiae PE-2 E Saccharomyces cerevisiae IZ-1904, E A CAPACIDADE DA VINHAÇA EM ATENUAR A TOXICIDADE ${ }^{1}$
}

\author{
Samuel MARIANO-DA-SILVA, S. ${ }^{2, *}$, Luiz Carlos BASSO ${ }^{3}$
}

\section{RESUMO}

O presente trabalho teve por finalidade estudar os efeitos do cádmio sobre a levedura Saccharomyces cerevisiae, bem como avaliar a possibilidade de se utilizar a vinhaça como fornecedora de agentes ligantes, visando minimizar os efeitos deletérios do mesmo. Primeiramente montou-se um ensaio visando observar a ação tóxica de diferentes concentrações de cádmio $(0 ; 0,05 ; 0,1$ e $0,5 \mathrm{mM})$, avaliada pelo crescimento de duas cepas da levedura S. cerevisiae (PE-2 e IZ-1904) em meio YED. O meio foi inoculado com $1 \mathrm{~mL}$ de uma suspensão a $1 \%(\mathrm{~m} / \mathrm{v})$ das respectivas cepas e incubado por 18 horas. Em tempos determinados durante o crescimento anaeróbio, alíquotas da suspensão de células foram retiradas e a concentração celular foi determinada. No final do ensaio, foram determinadas a viabilidade celular, a taxa de brotamento e a contaminação bacteriana. Os teores de trealose para cada tratamento, de ambas as cepas, foram dosados no início e no final do ensaio. Em uma segunda etapa, montou-se um ensaio visando avaliar a capacidade da vinhaça $(0,15$ e $30 \%$ do volume do meio) em atenuar os efeitos tóxicos de duas doses de cádmio $(0,1$ e $0,5 \mathrm{mM})$, empregando-se a levedura $S$. cerevisiae PE-2 em meio YED. O meio foi inoculado com $2 \mathrm{~mL}$ de uma suspensão a $1 \%(\mathrm{~m} / \mathrm{v})$ da levedura e incubado por $18 \mathrm{horas}$. Em tempos determinados durante o crescimento anaeróbio, alíquotas da suspensão de células foram retiradas e a concentração celular foi determinada. No final do ensaio, foram determinadas a viabilidade celular, a taxa de brotamento, a contaminação bacteriana e a produção de etanol. Os teores de trealose, para cada tratamento, foram dosados nas leveduras no início e no final do ensaio. O cádmio prejudicou o crescimento e a viabilidade celular das duas cepas da levedura S. cerevisiae. A vinhaça apresentou um discreto efeito tóxico, traduzido pela redução do crescimento. Porém, nos tratamentos contaminados com cádmio, apresentou um efeito protetor, minimizando os efeitos deletérios do metal.
\end{abstract}

Palavras-chave: levedura; cádmio; metais pesados; vinhaça; fermentação alcoólica.

\section{SUMMARY}

EFFECT OF CADMIUM ON THE GROWTH OF TWO Saccharomyces cerevisiae STRAINS, AND THE VINASSE CAPACITY TO ATENUATE THE TOXICITY. The present study was carried out in order to evaluate the capability of different cadmium concentration $(0 ; 0,05,0,10$ and $0,50 \mathrm{mM}$ ) to affect the growth of two S. cerevisiae strains (PE-2 and IZ-1904) in YED (yeast extract $1 \%$ and dextrose $2 \%$ ) medium, and to evaluate the three vinasse concentration capability $(0,15$ and $30 \%)$ to attenuate the two cadmium concentration toxicity $(0,1$ and $0,5 \mathrm{mM}$ ), using S. cerevisiae PE-2 strain in YED medium. In the first assay, the medium was inoculated in aseptic conditions with $1 \mathrm{~mL}$ of $1 \%$ yeast suspension (PE-2 or IZ-1904) and incubated at $30^{\circ} \mathrm{C}, 70$ RPM for 18 hours. During anaerobic growth $(0,2,4,6,8,10,12,14,16$ and 18 hours), portions of cell suspension were taken out and biomass concentration was determined. At the end of fermentation, yeast viability, budding rate and bacterial contamination were determined. Both, initial and final trehalose, was measured. In the second assay, the medium was inoculated in aseptic conditions with $2 \mathrm{~mL}$ of $1 \% \mathrm{PE}-2$ suspension and incubated at $30^{\circ} \mathrm{C}, 120 \mathrm{rpm}$ for 18 hours. During the anaerobic growth $(0,2,4,6,8,10,12,14,16$ and 18 hours) portions of cell suspension were taken out and biomass concentration was determined. At the end of fermentation, alcohol production, yeast viability, budding rate and bacterial contamination were determined. Both, initial and final trehalose, was measured. The increase of cadmium levels showed a reduction on yeast growth and cell viability. Vinasse showed low toxicity, but protected yeast cells very effectively against the toxic effects of cadmium.

Keywords: yeast; vinasse; cadmium; heavy metals; alcoholic fermentation.

\section{1 - INTRODUÇÃo}

A relação entre os vários microrganismos, especialmente bactérias, e os metais pesados é relativamente bem documentada. Porém, poucas informações sobre a resistência de leveduras frente aos metais pesados têm sido publicadas. O estudo das interações entre as leveduras e os metais pesados tem um alto interesse científico. Entre os fungos, as leveduras são as mais exploradas científicamente, devido ao fato de serem

\footnotetext{
1. Recebido para publicação em 20/09/2001. Aceito para publicação em 26/09/2003 (000734).

2. Universidade Federal de Goiás, Instituto de Ciências Biológicas, Campus Avançado de Jataí, Centro de Ciências Agrárias (UFG/ICB/CAJ/CCA). Br.364, Km. 192, Zona Rural, Cx. postal 03, CEP: 75.800-000, Jatai, Goiás.E-mail: smarianos@uol.com.br

3. Universidade de São Paulo, Escola Superior de Agricultura "Luiz de Queiroz", Departamento de Ciências Biológicas (ESALQ/USP) Av. Pádua Dias, n.11, Cx. postal.09, CEP.13.418-900 - Piracicaba, São Paulo. Email: lucbasso@esalq.usp.br

*A quem a correspondência deve ser enviada.
}

organismos eucariotos mais facilmente manipulados, e assim servir de excelente modelo para o estudo de muitos problemas importantes na biologia dos eucariotos [11].

As leveduras são também conhecidas por acumular grandes quantidades de metais pesados em meios aquosos [15]. Desta forma, quando estes microrganismos entram na cadeia alimentar, eles podem se tornar perigosos. Um exemplo de risco ecológico pode ser a produção industrial de Saccharomyces cerevisiae. O processo de fermentação alcoólica mais utilizado no Brasil é o Melle-Boinot, no qual as células de levedura recuperadas são recirculadas no processo. Entretanto, várias usinas desviam do processo parte do leite de levedura (10 a 20\%). Esta biomassa de leveduras é então utilizada na alimentação animal e humana como fonte de proteína.

O acúmulo de metais pesados por microrganismos é geralmente bifásico: uma rápida ligação com a superfície da célula, independente do metabolismo, é segui- 
da de um acúmulo intracelular dependente do metabolismo e com gasto de energia [14, 15, 22, 28]. Neste acúmulo não dependente do metabolismo (biosorção), os cátions podem ser depositados na membrana via adsorção, precipitação orgânica ou ficarem adsorvidos a grupos aniônicos fixos, presentes na membrana da célula [15, 30, 44]. O acúmulo independente do metabolismo é seguido de outro, dependente do metabolismo, onde grandes quantidades do metal podem ser bioacumuladas [13, 16, 24, 27, 29, 32, 34, 35, 36]. Os cátions são transportados através da membrana celular, provavelmente por proteínas de transporte, até o citossol, onde se associam a várias organelas ou ficam ligados a metaloproteínas [8, 28, 44].

Para leveduras a toxidade dos metais pesados pode ser conseqüência da formação direta de complexos, os quais modificam a atividade biológica de componentes celulares como ácidos nucléicos, enzimas ou aminoácidos $[9,19,21,31]$ assim como conseqüência de danos na parede celular $[1,2,35]$.

No presente trabalho foi testada a capacidade do cádmio em afetar o crescimento de duas cepas da levedura Saccharomyces cerevisiae a capacidade da vinhaça em atenuar os efeitos tóxicos, com o objetivo de coletar algumas informações da relação entre o cádmio e as leveduras.

\section{2 - MATERIAIS E MÉTODOS}

\section{1 - Preparo da vidraria}

Toda a vidraria reutilizável foi previamente imersa, por 4 horas, em uma solução de lavagem $\left(\mathrm{HNO}_{3}, \mathrm{HCl}\right.$ e água, na proporção 1:2:9) sendo a seguir enxaguada com água deionizada e seca em estufa a $80^{\circ} \mathrm{C}$ [26].

\section{2 - Preparo das soluções:}

Para limitar a possivel contaminação, todas as soluções utilizadas foram preparadas com água ultra pura (Sistema Millipore Milli-Q de purificação).

\section{3 - Cepas utilizadas}

Utilizou-se as leveduras Saccharomyces cerevisiae PE2 e Saccharomyces cerevisiae IZ-1904, ambas caracterizadas pelo método de cariotipagem [7], e oriundas da Coleção de Leveduras do Departamento de Ciências Biológicas (ESALQ/USP). Tais leveduras são amplamente empregadas pelo parque industrial brasileiro, e apresentam baixa (IZ-1904) e alta (PE-2) capacidade de sobrevivência nas dornas.

\section{4 - Pré-crescimento das leveduras}

Partindo de uma cultura pura (liofilizada), as leveduras foram reativadas em meio YEPD (extrato de levedura, peptona e dextrose) e pré-crescidas anaerobicamente a $30^{\circ} \mathrm{C}$ em um meio de melaço com $6 \%$ de açúcares redutores totais (ART), suplementado com $\mathrm{KH}_{2} \mathrm{PO}_{4}$ $(8,36 \mathrm{mM}),\left(\mathrm{NH}_{4}\right)_{2} \mathrm{SO}_{4}(5 \mathrm{mM})$, uréia $(38,75 \mathrm{mM}), \mathrm{MgSO}_{4} \cdot \mathrm{H}_{2} \mathrm{O}$
(3,57mM), $\mathrm{ZnSO}_{4} \cdot 7 \mathrm{H}_{2} \mathrm{O}(0,10 \mathrm{mM}), \mathrm{MnSO}_{4} \cdot \mathrm{H}_{2} \mathrm{O}(0,12 \mathrm{mM})$ e ácido linoléico $(0,11 \mathrm{mM})$ e esterilizado $\left(121^{\circ} \mathrm{C} / 1 \mathrm{~atm} /\right.$ 20 minutos). Após o crescimento as células foram coletadas por centrifugação (800G, 20min) e ressuspendidas em água destilada estéril a uma concentração de 1\% na massa úmida $(\mathrm{m} / \mathrm{v})$.

\section{5 - Primeiro ensaio de fermentação: análises do crescimento}

Os crescimentos foram levados a efeito em $75 \mathrm{~mL}$ de meio YED (extrato de levedura 1\% e dextrose 2\% autoclavado $1 \mathrm{~atm}, 121^{\circ} \mathrm{C}$ por 20 minutos), em frascos erlenmeyers de $125 \mathrm{~mL}$, tapados com folha de alumínio e acrescidos com acetato de cádmio $\left(\mathrm{CdC}_{4} \mathrm{H}_{6} \mathrm{OH} .2 \mathrm{H}_{2} \mathrm{O}\right)$, de forma que as concentrações finais do metal fossem $0 ; 0,05 ; 0,10$ e 0,50mM. Todos os tratamentos foram realizados em 3 repetições. O valor de $\mathrm{pH}$ dos meios foi ajustado a 5,5 utilizando uma solução de $\mathrm{H}_{2} \mathrm{SO}_{4} 0,1 \mathrm{M}$. Os frascos contendo os meios foram inoculados em condições assépticas, com $1 \mathrm{~mL}$ da suspensão a $1 \%$ da respectiva levedura (PE-2 ou IZ-1904), conforme o tratamento, e incubados a $30^{\circ} \mathrm{C}$, sob agitação (120rpm) por 18 horas. Em tempos determinados durante o crescimento $(0,2,4,6,8,19,12,14,16$ e 18 horas), $1 \mathrm{~mL}$ da suspensão de células foi retirado e transferido para tubos de ensaio com $9 \mathrm{~mL}$ de água deionizada estéril. A concentração de células foi determinada por leitura turbidimétrica, a 570nm, em espectrofotômetro Bausch \& Lomb, modelo Spectronic 88. A taxa de crescimento foi então calculada pela conversão das leituras em concentração de biomassa (g $100 \mathrm{~mL}^{-1}$ de meio) através de reta padrão anteriormente estabelecida para cada levedura. Todos os tratamentos foram feitos em triplicata.

\section{6 - Segundo ensaio de fermentação}

Os crescimentos foram levados a efeito em $75 \mathrm{~mL}$ de meio YED (extrato de levedura 1\% e dextrose 2\%, autoclavado a $1 \mathrm{~atm}, 121^{\circ} \mathrm{C}$ por 20 minutos) em frascos erlenmeyers de $125 \mathrm{~mL}$, tapados com folha de aluminio e acrescidos com acetato de cádmio $\left(\mathrm{CdC}_{4} \mathrm{H}_{6} \mathrm{OH} .2 \mathrm{H}_{2} \mathrm{O}\right)$, de forma que as concentrações finais do metal fossem 0,$0 ; 0,10$ e $0,50 \mathrm{mM}$ e com as diferentes proporções de vinhaça no meio ( 15 e $30 \%$ em volume). Todos os tratamentos foram realizados em 3 repetições. O pH dos meios foram ajustados a 5,5 utilizando uma solução de $\mathrm{H}_{2} \mathrm{SO}_{4} \mathrm{0}, 1 \mathrm{M}$. Os frascos contendo os meios foram inoculados em condições assépticas, com $2 \mathrm{~mL}$ da suspensão $1 \%(\mathrm{~m} / \mathrm{v})$ da levedura (PE-2), conforme o tratamento, e incubados a $30^{\circ} \mathrm{C}$, sob agitação (120rpm) por 18 horas. Os crescimentos foram avaliados em diferentes tempos $(0,2,4,6,8,10,12,14,16$ e 18 horas), conforme protocolo do ensaio 1, igualmente com 3 repetições.

\section{7 - Taxa de viabilidade, taxa de brotamento e con- taminação bacteriana}

No final do ensaio (18 horas), foram retirados $0,5 \mathrm{~mL}$ de cada suspensão, sendo as amostras diluídas e coradas com eritrosina e observadas em microscópio ótico 
para avaliação da viabilidade, taxa de brotamento e contaminação bacteriana [3].

\section{8 - Análise de trealose}

A trealose foi extraída de $60 \mathrm{mg}$ (peso fresco) de células com $2 \mathrm{~mL}$ de ácido tricloroacético $0,5 \mathrm{M}$, em banho de gelo por 20 minutos (a suspensão foi frequentemente agitada) seguida de centrifugação e separação do extrato sobrenadante $[42,43]$. Em duplicata, $0,2 \mathrm{~mL}$ de cada sobrenadante foram transferidos para tubos Pyrex diluindo-se com $0,3 \mathrm{~mL}$ de água. A seguir, foi adicionado $5 \mathrm{~mL}$ do reagente antrona $(125 \mathrm{mg}$ antrona e $2,5 \mathrm{~g}$ tiouréia em uma mistura de $65,2 \mathrm{~mL}$ de água e $187,5 \mathrm{~mL}$ de $\left.\mathrm{H}_{2} \mathrm{SO}_{4}\right)$. A reação transcorreu em banho de água $\left(100^{\circ} \mathrm{C}\right)$ por 10 minutos, seguida de resfriamento por 20 minutos em sala escura. A intensidade de cor formada foi mensurada em colorímetro (Klett-Summerson) a 620nm [10].

\section{9 - Análise do etanol formado}

Ao final das fermentações (18 horas), o etanol foi dosado no vinho delevurado mediante destilação com vapor (em microkjeldhal) seguido de densimetria eletrônica em densímetro Anton Paasr, modelo DMA 48 [45].

\subsection{0 - Análise estatística}

A análise de variância (teste de F) foi utilizada para analisar as variáveis crescimento, células viáveis e teor de trealose, seguida de uma análise seguindo um esquema fatorial no delineamento inteiramente casualizado, com modelo classificação cruzada dupla e 3 repetições. As comparações de médias foram feitas pelo teste de comparações múltiplas de Tukey [38].

\section{3 - RESULTADOS E DISCUSSÃO}

O cádmio foi tóxico para ambas as leveduras em todas as concentrações testadas $(0,05 ; 0,1$ e $0,5 \mathrm{mM})$ quando comparadas com o controle $(0,0 \mathrm{mM} \mathrm{Cd})$ nas duas variáveis testadas (crescimento e viabilidade), embora possa ser observado claramente que a levedura IZ-1904 foi mais sensivel ao cádmio (Tabela 1), apresentando um decréscimo na taxa de crescimento (Figuras 1 e 2). Além disto, a levedura IZ-1904, na concentração de $0,05 \mathrm{mM}$ de cádmio atrasou o final da fase Log em relação ao controle de 14 para 16 horas, o que já havia sido notado por GRAFL \& SCHWANTES [17]. Estes autores demonstraram que para Saccharomyces cerevisiae a toxidade para cádmio começa a se manifestar na concentração de $0,001 \mathrm{mM}$, e que $0,1 \mathrm{mM}$ impediu a divisão celular completamente.

Esta maior resistência ao cádmio demonstrada pela levedura PE-2, quando comparada com a levedura IZ1904 e a cepa utilizada por GRAFL \& SCHWANTES [17] já poderia ser esperada. Outros trabalhos $[5,6]$ já haviam demonstrado a maior tolerância da levedura PE-2 a diversos fatores estressantes, tais como etanol, temperatura, sorbitol, apresentando melhores médias de viabilidade, crescimento e rendimento fermentativo, quando comparada com outras leveduras.

Conforme esperado, os teores de trealose nas duas leveduras diminuiram em relação ao controle com o aumento da concentração de cádmio, sendo porém anormal os teores elevados encontrados para ambas as cepas no tratamento com $0,5 \mathrm{mM}$. Este comportamento pode ser explicado pelo não crescimento das cepas nesta concentração de cádmio (Figuras 1 e 2). As células provavelmente se encontram em um estado de semi-letargia, não sendo capazes de metabolizar a glicose do meio de fermentação, e utilizando as reservas endógenas iniciais lentamente, até o esgotamento destas. Isto é ainda mais palpável quando se compara a viabilidade das leveduras submetidas a este tratamento com as demais.

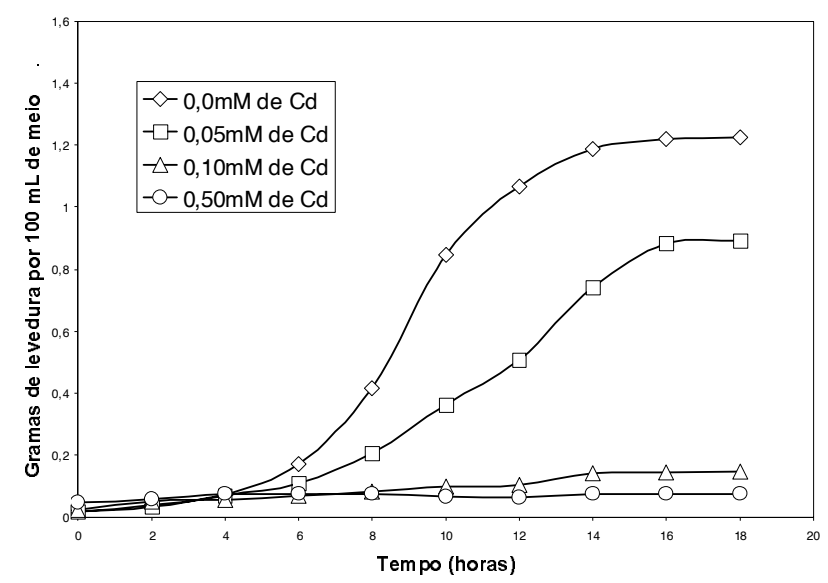

FIGURA 1. Crescimento da levedura IZ-1904 em meios contendo concentrações crescentes de cádmio.

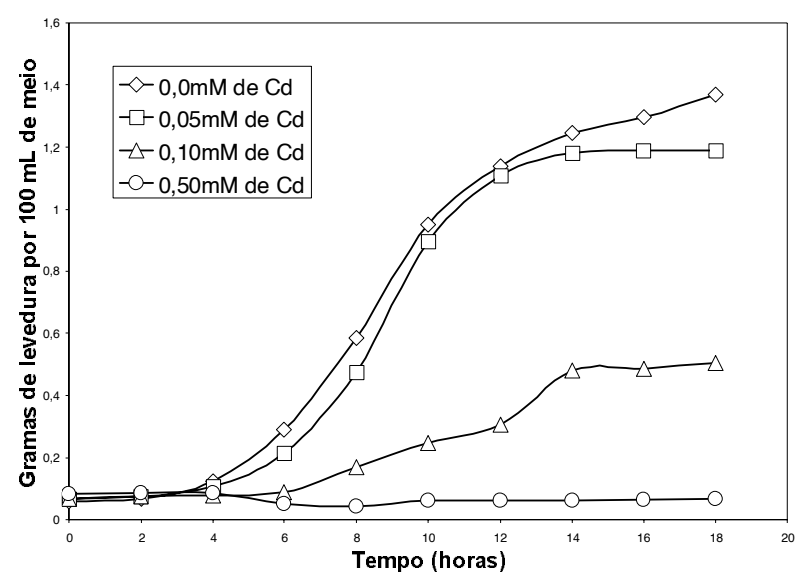

FIGURA 2. Crescimento da levedura PE-2 em meios contendo concentrações crescentes de cádmio.

Os teores de trealose nas leveduras decresceram com o aumento das doses de cádmio e conseqüente queda na viabilidade (Tabelas 1, 2 e 3). A trealose é um dissacarídeo não redutor constituído de duas unidades de glicose, e parece exercer um efeito protetor sobre as 
células de levedura durante processos de estresse [23]. O modelo mais aceito para explicar o efeito protetor da trealose é o proposto por CROWE et al. [12]. Segundo os autores, a trealose interage com os grupos polares das cadeias fosfolipídicas existentes na membrana, substituindo a água que está ligada às cabeças polares dos fosfolipídios quando em condições favoráveis e seria perdida no processo de estresse. Com a ligação da trealose à membrana não há alteração do espaçamento entre os fosfolipídios, evitando assim as separações laterais dos componentes da membrana. Com a substituição das moléculas de água pela trealose, mantémse a integridade e a fluidez da membrana, e assim, a viabilidade celular.

TABELA 1. Taxa de viabilidade (\%)

\begin{tabular}{cccccc}
\hline & \multicolumn{5}{c}{ Tratamento $\left(\mathrm{Cd} \mathrm{L}^{-1}\right)$} \\
\cline { 2 - 6 } IZ-1904 & Inicial & $0,00 \mathrm{mM}$ & $0,05 \mathrm{mM}$ & $0,10 \mathrm{mM}$ & $0,50 \mathrm{mM}$ \\
\cline { 2 - 5 } PE-2 & $98,32 \mathrm{Aa}$ & $87,73 \mathrm{Aa}$ & $80,03 \mathrm{Ba}$ & $65,72 \mathrm{Ca}$ & $89,80 \mathrm{Aa}$ \\
& $99,18 \mathrm{Aa}$ & $94,74 \mathrm{Aa}$ & $86,66 \mathrm{Ba}$ & $59,86 \mathrm{Ca}$ & $86,32 \mathrm{Ba}$ \\
\hline \multicolumn{4}{c}{ COEFICIENTE DE VARIAÇÃO: A $=4,95 \mathrm{~B}=5,94$}
\end{tabular}

As médias seguidas pelas mesmas letras (maiúsculas ou minúsculas), não diferem entre sí dentro de uma mesma linha ou mesma coluna, de acordo com o teste de Tukey a $1 \%$ de significância.

TABELA 2. Taxa de brotamento (\%)

\begin{tabular}{cccccc}
\hline \hline & \multicolumn{5}{c}{ Tratamento $\left(\mathrm{Cd} \mathrm{L}^{-1}\right)$} \\
\cline { 2 - 6 } IZ-1904 & Inicial & $0,00 \mathrm{mM}$ & $0,05 \mathrm{mM}$ & $0,10 \mathrm{mM}$ & $0,50 \mathrm{mM}$ \\
\cline { 2 - 5 } PE-2 & $9,22 \mathrm{Aa}$ & $13,18 \mathrm{Aa}$ & $12,95 \mathrm{Aa}$ & $11,06 \mathrm{Ab}$ & $1,60 \mathrm{Bb}$ \\
& $9,05 \mathrm{Ba}$ & $29,78 \mathrm{Ab}$ & $15,70 \mathrm{Ba}$ & $19,12 \mathrm{Aa}$ & $11,46 \mathrm{Ba}$ \\
\hline \multicolumn{5}{c}{ COEFICIENTE DE VARIAÇÃO: $\mathrm{A}=14,98 \mathrm{~B}=17,65$}
\end{tabular}

As médias seguidas pelas mesmas letras (maiúsculas ou minúsculas), não diferem entre si dentro de uma mesma linha ou mesma coluna, de acordo com o teste de Tukey a $1 \%$ de significância.

TABELA 3. Teor de trealose (\%)

\begin{tabular}{cccccc}
\hline & \multicolumn{5}{c}{ Tratamento (Cd) } \\
\cline { 2 - 6 } IZ-1904 & Inicial & $0,00 \mathrm{mM}$ & $0,05 \mathrm{mM}$ & $0,10 \mathrm{mM}$ & $0,50 \mathrm{mM}$ \\
\cline { 2 - 6 } PE-2 & $2,50 \mathrm{Aa}$ & $2,31 \mathrm{Aa}$ & $0,50 \mathrm{Ca}$ & $0,56 \mathrm{Ca}$ & $1,59 \mathrm{Ba}$ \\
& 3,56Aa & $3,63 \mathrm{Aa}$ & $0,17 \mathrm{Ca}$ & $0,20 \mathrm{Ca}$ & $1,31 \mathrm{Ba}$ \\
\hline \multicolumn{6}{c}{ COEFICIENTE DE VARIAÇÃO: A = 13,99 B = 11,78 } \\
\hline
\end{tabular}

As médias seguidas pelas mesmas letras (maiúsculas ou minúsculas), não diferem entre si dentro de uma mesma linha ou mesma coluna, de acordo com o teste de Tukey a $1 \%$ de significância.

TABELA 4. Álcool (\%)

\begin{tabular}{ccccc}
\hline \hline & \multicolumn{4}{c}{ Tratamento (Cd) } \\
\cline { 2 - 5 } IZ-1904 & $0,00 \mathrm{mM}$ & $0,05 \mathrm{mM}$ & $0,10 \mathrm{mM}$ & $0,50 \mathrm{mM}$ \\
\cline { 2 - 5 } PE-2 & $1,00 \mathrm{Aa}$ & $0,88 \mathrm{Aa}$ & $0,45 \mathrm{Bb}$ & $0,00 \mathrm{Ca}$ \\
& $1,03 \mathrm{Aa}$ & $0,98 \mathrm{Aa}$ & $0,69 \mathrm{Ba}$ & $0,00 \mathrm{Ca}$ \\
\hline \hline
\end{tabular}

As médias seguidas pelas mesmas letras (maiúsculas ou minúsculas), não diferem entre si dentro de uma mesma linha ou mesma coluna, de acordo com o teste de Tukey a $1 \%$ de significância.

O cádmio é conhecido por interagir com os polifosfatos da membrana plasmática da levedura [38, 39]. Como estes polifosfatos atuam no transporte de glicose para dentro da célula $[11,22,37,40,41]$ este transporte deve ter sido completamente inibido nesta concentração de cádmio $(0,5 \mathrm{mM})$. Provavelmente as leveduras se encontram em um estado de semi-letar- gia, não sendo capazes de metabolizar a glicose do meio de fermentação, utilizando para sobreviver as suas reservas endógenas (nitrogênio, trealose e glicogênio). Quando do esgotamento destas reservas, ocorrerá a morte destas células.

A utilização das reservas de trealose e glicogênio poderia até mesmo explicar o aumento dos teores de proteína em leveduras submetidas a $0,042 \mathrm{mM}$ de cádmio, obtido por SILVA [35], SILVA \& PRADO-FILHO [36] e MARIANO-DA-SILVA \& PRADO-FILHO [27], assim como o aumento do teor alcóolico de vinhos oriundos da fermentação de mostos de melaço contaminados com 0,042mM de cádmio, obtidos por PRADO-FILHO, DOMINGOS \& SILVA [29] e DOMINGOS [13], o que não foi discutido pelos autores pela falta de subsídios pela não mensuração dos teores de trealose.

O aumento das concentrações de cádmio coincidiu com a diminuição na produção de álcool (Tabela 3). Provavelmente, com a diminuição da absorção de glicose, a glicólise foi prejudicada, ocorrendo diminuição no metabólito final desta via metabólica.

A vinhaça mostrou um pequeno efeito depressivo sobre o crescimento (Figura 3), porém sem afetar a viabilidade celular (Tabelas 4 e 5). Os resultados mostraram claramente que a vinhaça atenuou o efeito tóxico do cádmio (Tabela 6, Figuras 4, 5 e 6). Ficou também bem evidenciado que a maior dose de vinhaça exerceu um efeito protetor maior. Estas afirmações ficam ainda mais evidentes quando confrontamos os resultados de viabilidade (Tabela 5), os teores de trealose (Tabela 7) e os valores de álcool no vinho (Tabela 8).

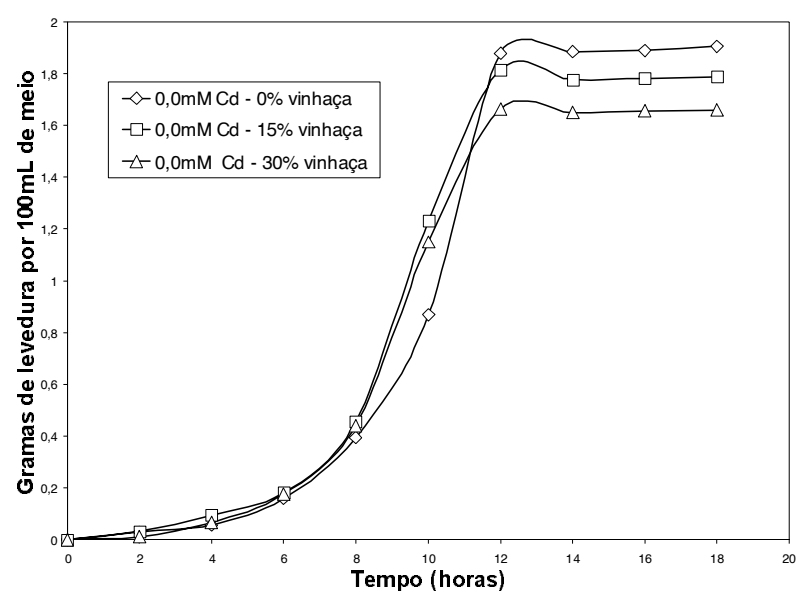

FIGURA 3. Crescimento da levedura PE-2 em presença de vinhaça no meio $(0,15$ e $30 \%)$.

Esta proteção proporcionada pela vinhaça pode ser atribuída às interações pouco conhecidas entre o cádmio e os compostos orgânicos e inorgânicos presentes em um meio complexo [4]. A ação individual de grupos orgânicos, quelantes e seqüestradores, com ligações como R-S- $\mathrm{SO}_{4}^{-2}, \mathrm{~F}^{-}, \mathrm{NO}_{3}{ }^{-}, \mathrm{NH}_{3}$, etc. é desconhecida [29], bem como as interações no ambiente fermentativo de um mosto YED-vinhaça; por outro lado, a vinhaça é 
conhecidamente rica em compostos minerais tais como cálcio, zinco, enxofre, etc. [33], que como foi demonstrado por vários autores [2, 18, 20, 25, 28] podem por competição ou complexação atenuar a toxidade do cádmio sobre a levedura.

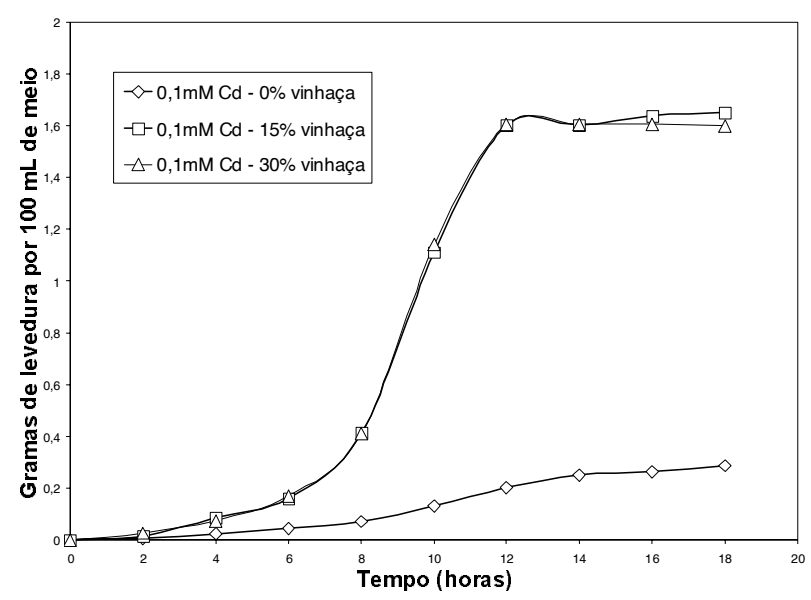

FIGURA 4. Crescimento da levedura PE-2 em meio com $0,1 \mathrm{mM} \mathrm{L}^{-1}$ de cádmio e diferentes concentrações de vinhaça $(0,15$ e $30 \%)$.

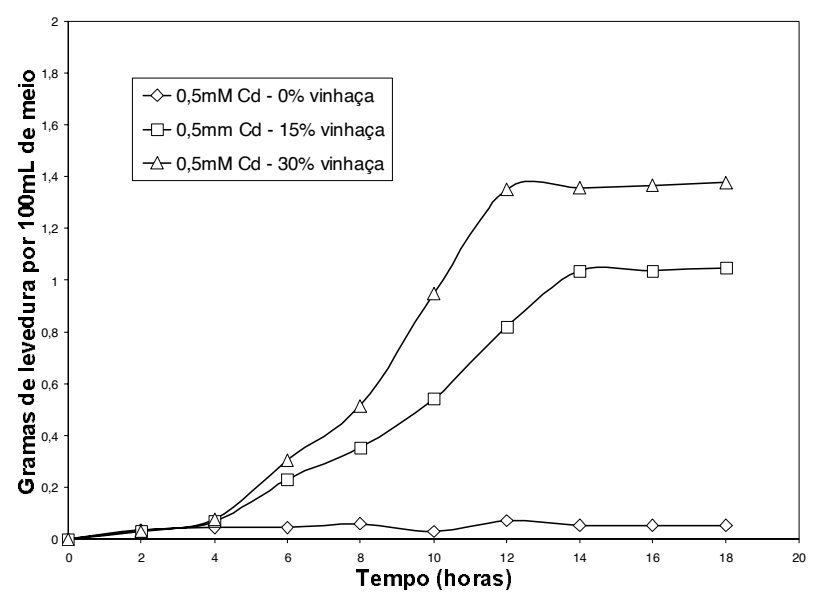

FIGURA 5. Crescimento da levedura PE-2 em meio com $0,5 \mathrm{mM}$ de cádmio e diferentes concentrações de vinhaça $(0,15$ e $30 \%)$.

TABELA 5. Taxa de viabilidade (\%)

\begin{tabular}{lcccc}
\hline \hline & \multicolumn{4}{c}{ Tratamento $\left(\mathrm{Cd} \mathrm{L}^{-1}\right)$} \\
\cline { 2 - 5 } $0 \%$ vinhaça & Inicial & $0,00 \mathrm{mM}$ & $0,10 \mathrm{mM}$ & $0,50 \mathrm{mM}$ \\
\cline { 2 - 5 } $15 \%$ vinhaça & $99,74 \mathrm{Aa}$ & $99,54 \mathrm{Aa}$ & $67,40 \mathrm{Bb}$ & $0,00 \mathrm{Cb}$ \\
$30 \%$ vinhaça & $99,74 \mathrm{Aa}$ & $99,83 \mathrm{Aa}$ & $99,68 \mathrm{Aa}$ & $99,44 \mathrm{Aa}$ \\
& $99,74 \mathrm{Aa}$ & $100,00 \mathrm{Aa}$ & $99,44 \mathrm{Aa}$ & $99,48 \mathrm{Aa}$ \\
\hline \multicolumn{5}{c}{ COEFICIENTE DE VARIAÇÃO: $\mathrm{A}=5,67 \mathrm{~B}=4,32$} \\
\hline
\end{tabular}

As médias seguidas pelas mesmas letras (maiúsculas ou minúsculas), não diferem entre si dentro de uma mesma linha ou mesma coluna, de acordo com o teste de Tukey a $1 \%$ de significância.
TABELA 6. Taxa de brotamento (\%)

\begin{tabular}{lcccc}
\hline & \multicolumn{4}{c}{ Tratamento $\left(\mathrm{Cd} \mathrm{L}^{-1}\right)$} \\
\cline { 2 - 5 } $0 \%$ vinhaça & Inicial & $0,00 \mathrm{mM}$ & $0,10 \mathrm{mM}$ & $0,50 \mathrm{mM}$ \\
\cline { 2 - 5 } $15 \%$ vinhaça & $18,50 \mathrm{Aa}$ & $22,07 \mathrm{Aa}$ & $6,31 \mathrm{Bb}$ & $0,00 \mathrm{Cb}$ \\
$30 \%$ vinhaça & $18,50 \mathrm{Aba}$ & $22,71 \mathrm{Aa}$ & $16,15 \mathrm{Ba}$ & $23,11 \mathrm{Aa}$ \\
\hline \hline & COEFICIENTE DE VARIAÇÃO: $\mathrm{A}=2.34 \mathrm{~B}=3,45$ \\
\hline
\end{tabular}

As médias seguidas pelas mesmas letras (maiúsculas ou minúsculas), não diferem entre si dentro de uma mesma linha ou mesma coluna, de acordo com o teste de Tukey a $1 \%$ de significância.

TABELA 7. Teor de trealose (\%)

\begin{tabular}{ccccc}
\hline \hline & \multicolumn{4}{c}{ Tratamento $\left(\mathrm{Cd} \mathrm{L}^{-1}\right)$} \\
\cline { 2 - 5 } $0 \%$ vinhaça & Inicial & $0,00 \mathrm{mM}$ & $0,10 \mathrm{mM}$ & $0,50 \mathrm{mM}$ \\
\cline { 2 - 5 } $15 \%$ vinhaça & $1,41 \mathrm{Aa}$ & $1,35 \mathrm{Aa}$ & $0,05 \mathrm{Bb}$ & $0,00 \mathrm{Bb}$ \\
$30 \%$ vinhaça & $1,41 \mathrm{Aa}$ & $0,48 \mathrm{Bb}$ & $0,11 \mathrm{Cb}$ & $0,40 \mathrm{Ba}$ \\
& $1,41 \mathrm{Aa}$ & $1,20 \mathrm{Aa}$ & $0,52 \mathrm{Ba}$ & $0,52 \mathrm{Ba}$ \\
\hline
\end{tabular}

As médias seguidas pelas mesmas letras (maiúsculas ou minúsculas), não diferem entre si dentro de uma mesma linha ou mesma coluna, de acordo com o teste de Tukey a $1 \%$ de significância.

TABELA 8. Álcool (\%)

\begin{tabular}{cccc}
\hline \hline & \multicolumn{3}{c}{ Tratamento $\left(\mathrm{Cd} \mathrm{L}^{-1}\right)$} \\
\cline { 2 - 4 } $0 \%$ vinhaça & $0,0 \mathrm{mM}$ & $0,10 \mathrm{mM}$ & $0,50 \mathrm{mM}$ \\
\cline { 2 - 4 } $15 \%$ vinhaça & $0,97 \mathrm{Aa}$ & $0,71 \mathrm{Bb}$ & $0,00 \mathrm{Cb}$ \\
$30 \%$ vinhaça & $1,03 \mathrm{Aa}$ & $1,09 \mathrm{Aa}$ & $1,06 \mathrm{Aa}$ \\
& $1,03 \mathrm{Aa}$ & $1,09 \mathrm{Aa}$ & $1,06 \mathrm{Aa}$ \\
\hline \hline
\end{tabular}

As médias seguidas pelas mesmas letras (maiúsculas ou minúsculas), não diferem entre si dentro de uma mesma linha ou mesma coluna, de acordo com o teste de Tukey a $1 \%$ de significância.

\section{4 - CONCLUSÕES}

O cádmio, ainda que em baixas concentrações, prejudica o crescimento de leveduras, mesmo aquelas conhecidamente resistentes a fatores estressantes. A vinhaça apresenta um discreto efeito tóxico sobre a levedura, traduzido pela redução do crescimento. Apesar disto, quando observamos os tratamentos contaminados com cádmio, notamos claramente seu efeito protetor, minimizando os efeitos deletérios do metal. Os valores de trealose mostraram uma ótima correlação com viabilidade e crescimento da levedura, sendo que este parâmetro reflete o estado fisiológico de estresse ao qual a levedura está submetida. O uso da vinhaça como inibidor da toxicidade, não só do cádmio mas também de outros metais pesados, tem potencial, e merece ser alvo de estudos mais detalhados, inclusive sobre a bioacumulação destes metais.

\section{5 - REFERÊNCIAS BIBLIOGRÁFICAS}

[1] ALBERTINI, S. Isotermas de adsorção de cádmio por Saccharomyces cerevisiae. Piracicaba, 1999. 54 p. Dissertação (mestrado) - Escola Superior de Agricultura "Luiz de Queiroz", Universidade de São Paulo.

[2] ASSMANN, S.; SIGLER, K.; HÖFER, M. $\mathrm{Cd}^{2+}$ induced damage to yeast plasma membrane and its alleviation by $\mathrm{Zn}^{2+}$ : studies on Schizosaccharomyces pombe and reconstituted plasma membrane vesicles. Archive of Microbiology, v.165, n.4, p.279-284, 1996. 
[3] AMORIM, H. V.; OLIVEIRA, A. J.; ZAGO, E. A.; BASSO, L. C.; GALLO, C. R. Processos de fermentação alcoólica, seu controle e monitoramento. Piracicaba, São Paulo: FERMENTEC. 145 p, 1989.

[4] BAGY, M. M. K.; EL-ShAROUNY, H. M. M.; ELSHANAWANY, A. A. Effect of $\mathrm{pH}$ and organic matter on toxicity of heavy metals to growth of some fungi. Folia Microbiologica, v.36, n.4, p.367-374, 1991.

[5] BASSO, L. C.; AMORIN, H. V. Habilidade fermentativa de leveduras isoldas do processo industrial. Relatório Anual de Pesquisas em Fermentação Alcoólica, v.16, n.01, p.52-76, 1996.

[6] BASSO, L. C.; AMORIN, H. V. Estudo comparativo de leveduras selecionadas do processo industrial. Relatório Anual de Pesquisas em Fermentação Alcoólica, v.15, n.01, p.57-106, 1995.

[7] BASSO, L. C.; OLIVEIRA, A. J.; ORELli, V. F. D. M.; CAMPOS, A. D.; GALLO, C. R.; AMORIM, H. V. Dominace of wild yeast over industrial yeast strain evaluated by karyotiping technique. Yeast Newsletter, v.52, n.2, p.50, 1993.

[8] BRADY, D.; DUNCAN, J. R. Bioacumulation of metal cations by Saccharomyces cerevisiae. Applied Microbiology and Biotechnology, v.41, n.01, p.149-159, 1994.

[9] BRENNAN, R. J.; SCHIESTL, R. H. Cadmium is an induces of oxidative stress in yeast. Mutation Research, v.356, n.1, p.171-178, 1996.

[10] BRIN, M. Tranketalose: clinical aspects. Methods in enzimology, v.9, p.606-514, 1966.

[11] BROCK, T. D.; MADIGAN, M. T.; MARTINKO, J. M.; PARKER, J. Biology of Microorganisms, $7^{\mathrm{a}}$ ed. New Jersey, Prentice Hall 1994, 909p.

[12] CROWE, J.H.; PANEK, A.D.; CROWE, L.M.; PANEK, A.C.; ARAÚJO, P.S. Trehalose transport in yeast cell. Biochemistry International, v.24, n.4, p.721-730, 1991.

[13] DOMingos, R. N. Acúmulo de cádmio por Saccharomyces cerevisiae fermentando mosto de melaço. Piracicaba, 1996. 63 p. Dissertação (Mestrado) - Escola Superior de Agricultura "Luiz de Gueiroz", Universidade de São Paulo.

[14] GADD, G. M. Fungal responses towards heavy metals. In: HERBERT, R. A.; COOD, G. A. Microbes in Extreme Environments, 1986a. New York, Academic Press. cap.4, p.83-110.

[15] GADD, G. M. The uptake of heavy metals by fungi and yeasts: the chemistry and physiology of the process and applications for biotechnology. In: ECCLES, H; HUNT, S. Immobilization of Ions by Bio-sorption, 1986b. London, Ellis Horwood Limited Publishers. cap. 5.2, p.135-147.

[16] GADD, G. M. and MOWLL, J. L. The relationship between cadmium uptake, potassium release and viability in Saccharomyces cerevisiae. FEMS Microbiology Letters, v.16, n.1, p.45-48, 1983.

[17] GRAFL, H. J.; SCHWANTES, H. O. Der Einfluss von Cadmium, Zink, Blei und Quecksilber auf das Wachstum und das Akkumulationsvermögen von Saccharomyces cerevisiae, Saccharomyces lipolytica, Candida tropicalis und Candida utilis. Zentralblatt fur Bakteriologie, Mikrobiologie und Hygiene - serie B - Umwelthygiene Krankenhaushygiene Arbeitshygiene Präventive Medizin, v.177, n.(1-2), p.57-74, 1983a.

[18] GRAFL, H. J.; SCHWANTES, H. O. Der Einfluss von Cadmium, Zink, Blei und Quecksilber auf die Atmung und Gärung von Saccharomyces cerevisiae. Angewandte Botanik, v.57, n.(1-2), p.31-43, 1983b.
[19] GRAFL, H. J.; SCHWANTES, H. O. Der Einfluss von Cadmium, Zink, Blei und Quecksilber auf die Enzymaktivität bei Saccharomyces cerevisiae in vitro. Zeitschrift für Ernährungswiessenschaft, v.22, n.3, p.205-212, 1983c.

[20] GRAFL, H. J.; SCHWANTES, H. O. Der Einfluss von Schwermetallinteraktionen auf das Wachstum von Saccharomyces cerevisiae. Zentralblatt fur Bakteriologie, Mikrobiologie und Hygiene - serie B - Umwelthygiene Krankenhaushygiene Arbeitshygiene Praventive Medizin, v.177, n.6, p.514-526, 1983d.

[21] GRAFL, H. J.; SCHWANTES, H. O. Der Einfluss von Cadmium, Zink, Blei und Quecksilber auf die Enzymaktivität bei Saccharomyces cerevisiae in vivo. Zentralblatt fur Mikrobiologie, v.140, n.1, p.3-11, 1985.

[22] GRIFFIN, D. H. Fungal Physiology, 2 ${ }^{\text {a }}$ ed. New York, Willey-Liss, 1993, 458p.

[23] GUTIERREZ, L. E. Tópicos de bioquímica de leveduras. Piracicaba: Núcleo de Apoio à pesquisa em Microbiologia Agrícola, 103p., 1994.

[24] HeldWein, R.; TROMBAll, H. W.; BRODA, E. Aufnahme von Cobalt, Blei und Cadmium durch Bäckerhefe. Zeitschrift für Allgemeine Mikrobiologie, v.17, n.4, p.299-308, 1977.

[25] KESSELS, B. G. F.; BELDE, P. M. J.; BORST-PAUWELS, G. W. F. H. Protection of Saccharomyces cerevisiae against $\mathrm{Cd}^{2+}$ toxicity by $\mathrm{Ca}^{2+}$. Journal of General Microbiology, v.131, n.10, p.2.533-2.537, 1985.

[26] McDANIEL, W. Sample preparation procedure for spectrochemical determination of total recoverable elements in biological tissues. In: SMOLEY, C. K. Methods for the determination of metals in environmental samples. Boca Ranton, Flórida: CRC Press Inc. 1992. cap. 3, p.25-32.

[27] MARIANO-DA-SILVA, S.; PRADO-FILHO, L. G. Acúmulo de Cádmio por Saccharomyces cerevisiae em caldo de cana-de-açúcar contaminado com acetato de cádmio. Scientia Agrícola, v.56, n.2, p.427-431, 1999.

[28] NORRIS, P. R.; KELLY, D. P. Accumulation of cadmium and cobalt by Saccharomyces cerevisiae. Journal of General Microbiology, v.99, n.2, p.317-324, 1977.

[29] PRADO-FILHO, L. G.; DOMINGOS, R. N.; SILVA, S. M. G. Acúmulo de cádmio por Saccharomyces cerevisiae fermentando mosto de melaço. Scientia Agrícola, v. 55, n.1, p.128-132, 1998 .

[30] REMACLE, J. The cell wall and the metal binding. In. Volesk, B. Biosorption of Heavy Metals, 1990. Boca Ranton, CRC Press. Cap.2.1, p.82-92.

[31] ROMANDINI, P.; TALLANDINI, L.; BELTRAMINI, M.; SALVATO, B.; MANZANO, M.; De-BERTOLDI, M.; ROCCO, G. P. Effects of copper and cadmium on growth, superoxide dismutase and catalase activities in different yeast strains. Comparative Biochemistry and Physiology - C - Pharmacology, Toxicology and Endocrinology, v.103, n.2, p.255-262, 1992.

[32] RÖSICK, E.; MANGIR, M.; LOCHMANN, E. R. Unterschiedliche Aufnahme von Cadmium in Saccharomyces - BZW. Rhodotorula - Zellen. Chemosphere, v.15, n.8, p.981-983, 1986.

[33] SILVA, G. M. A.; ORLANDO FILHO, J. Caracterização da composição química dos diferentes tipos de vinhaça do Brasil. Boletim Técnico PLANALSUCAR, v.3, n.8, 1981, 22p.

[34] SILVA, S. M. G. Acúmulo de cádmio por Saccharomyces cerevisiae fermentando mosto de caldo de cana. Piracicaba, 1998. 52 p. Dissertação (Mes- 
trado) - Escola Superior de Agricultura "Luiz de Queiroz", Universidade de São Paulo.

[35] SILVA, S. M. G. Efeitos do cádmio sobre a fermentacão alcoólica e o uso da vinhaça para atenuar a sua ação tóxica Piracicaba, 2001. 142 p. Tese (Doutorado) - Escola Superior de Agricultura "Luiz de Gueiroz", Universidade de São Paulo

[36] SILVA, S. M. G.; PRADO-FILHO, L. G. Acúmulo de cádmio por Saccaromyces cerevisiae fermentando mosto de caldo-de-cana. Ciênc. Tecnol. Aliment., v.18, n.4, p.410-413, 1998.

[37] SMITH, C. A.; WOOD, E. J. Cell Biology. $2^{\text {a }}$ ed., Hong Kong: Chapman \& Hall, 540 p. 1996.

[38] SNEDECOR, G. W.; COCHRAN, W. G., 1967. Statistical methods, $6^{\text {a }}$ ed. Iowa, USA: The Iowa State University Press. 593p.

[39] STEVENINCK, J. V. The influence of nickelous ions on carbohydrate transport in yeast cells. Biochimica et Biophysica ACTA, v.126, n.1, p.154-162, 1966.

[40] TIJSSEN, J. P. F.; BEEKES, H. W.; STEVENINCK, J. Localization of polyphosphates at the outside of the yeast cell plasma membrane. Biochimica et Biophsica ACTA, v.649, p.529-532, 1981.

[41] STEVENINCK, J. V.; BOOIJ, H. L. The role of polyphosphates in the transport mechanism of glucose in yeast cells. Journal of General Physiology, v.48, n.1, p.43-60, 1964.

[42] TREVELYAN, W. E.; HARRISON, J. S. Studies on yeast metabolism 5. The trehalose content of baker's yeast during anaerobic fermentation. Biochemical Journal, v.62, p.177-183, 1956a.

[43] TREVELYAN, W. E.; HARRISON, J. S. Studies on yeast metabolism 7. Yeast carbohydrate fraction. Separation from nucleic acid analysis and behaviour during anaerobic fermentation. Biochemical Journal, v.63, p.23-33, 1956b.

[44] VOLESKY, B. Biosorption by fungal biomass. In. Volesk, B. Biosorption of Heavy Metals, 1990. Boca Ranton, CRC Press. Cap. 23, p.139-172.

[45] ZAGO, E. A.; AMORIM, H. V.; BASSO, L. C.; GUTIERREZ, L. E.; OLIVEIRA, A. J. Métodos analiticos para o controle da producão de álcool. Piracicaba, São Paulo: FERMENTEC/ESALQ-USP. 144p, 1989.

\section{6 - AGRADECIMENTOS}

Este trabalho foi financiado pela FAPESP (Fundação de Amparo à Pesquisa do Estado de São Paulo) Processo $n^{\circ}$ 98/13743-0 tipo DR. 